\title{
Impact of Personality on Career Success of the Employees in the Sri Lankan Banking Sector in Western Province
}

\author{
Dodangoda, $\mathrm{HC}$ and Arachchige, BJH
}

\begin{abstract}
Area of the Study

As an important determinant of career success of an employee, this study is to investigate the impact of personality on career success of employees in Sri Lankan banking sector. There is an empirical and knowledge gap in the Sri Lankan context on this research area.

\section{Problem of the Study}

The major objective of this research study is to examine whether personality has an impact on the career success of the employees in Sri Lankan Banking sector. The research problem of this study: whether personality has an impact on the career success of the employees in the Sri Lankan banking sector in Western province.
\end{abstract}

\section{Method of the Study}

The data were collected from a convenient sample of 150 employees in commercial banks in Sri Lanka by using a structured questionnaire which consisted of 59 questions. Data was analyzed using univariate analysis, correlation and regression analysis with the SPSS 16.0 (Version).

\section{Findings of the Study}

According to the findings of the study personality has an impact on career success. Extraversion, openness to experience, agreeableness and conscientiousness relate with objective career success positively and further emphasizing positive relationship between conscientiousness and subjective career success. Justifying the empirical evidences it is revealed that there is a negative relationship between neuroticism and both objective and subjective career success.

\section{Conclusion of the Study}

It is concluded that individual's personality traits influence the objective and subjective career success. Overall personality has an impact on career success of the employees in the Sri Lankan banking sector in Western province.

Keywords: Personality, Big Five Model, Objective Career Success, Subjective Career Success

\section{Introduction}

Career of a person can be identified as a series of jobs that a particular person had gone through in his or her life. According to Melamed (1996) throughout their career, employees make choices and judgments that have strong implications on their career path, progress and success and this perspective has viewed the employees as actively involved in changing and shaping their career prospects. Career success can be defined as the positive psychological outcomes or achievements one has accumulated as a result of experiences over the span of work life (Judge et al. 1995). 
According to Judge et al. (1995) career success can be assumed to comprise objective or extrinsic and subjective or intrinsic elements, and the variables that lead to objective career success often are quite different from those that lead to subjectively defined success. Objective career success can be considered as the extrinsic success which is relatively objective and observable, and typically consists of highly visible outcomes such as pay and ascendancy (Jaskolka, Beyer \& Trice cited in Judge et al. 1999). Subjective career success reflects an individual's perception of their own success and self - evaluations of career success, not only in an employee's current organization, but also during their career in general (Toit and Coetzee 2012).

A number of research have been undertaken to determine the factors affecting career success by different researchers over time. One's personal characteristics or the personality was deemed to be the fourth key factor for career survival and success (Simonetti 1999). It was revealed that personality as one factor which determines career success. The way in which one behaves both on personal as well as on the job was deemed to be one main factor and personality has a great impact on how the person behave in both circumstances (Simonetti 1999). According to Lau and Shaffer (1999) the understanding that personality is a determinant of career success will be advantageous for individuals, organizations and career consultants. Thus all the empirical evidences suggest that career success can be affected by the personality of the individuals and the impact vary from occupation to occupation.

\section{Problem Background and Problem of the Study}

Lau and Shaffer (1999) argued that career success is a mode for individuals to accomplish their need for achievement and power because it develops people's quantity or quality of life, the study of who can get ahead and why it is of interest and value. However, it is not guaranteed that every person who starts his or her career will be successful. There are number of factors affecting to career success of a person. According to survey of more than 5,000 managers in Fortune 1,000 firms 20 factors which determine career success and personality were identified as the fourth important factor (Simonetti 1999). Among personality theories Big Five personality model is predominant and number of studies have revealed that Big Five traits were more strongly related to career success (Judge et al. 1999).

According to the preliminary interviews done by the researchers with the bankers who hold top positions in Sri Lankan commercial banks, it was revealed that qualifications and knowledge is not the only thing which made their career a success. In contrast, personality or personal attributes of a person also plays a huge role in one's career success. In the Sri Lankan context it is not known whether researches were done on this area in the banking sector. Thus, it is required to fulfill a knowledge gap in this field. This research therefore, attempts to identify the impact of personality on career success of the Sri Lankan banking sector employees. 


\section{Research Framework}

Previous literature supported that personality is a factor which influences career of a person. According to Judge et al. (1999) the traits discussed in Big Five model are related to career success.

Recent studies conducted in the United Kingdom suggest that extraversion was also predictive of salary and job level (Melamed 1996) which can be considered as the indicators of objective career success. Judge et al. (1999) argued that high extraversion was associated with extrinsic career success. Therefore the following hypothesis was developed;

$H_{1}$ : There is a positive relationship between extraversion and objective career success of the employees in Sri Lankan banking sector

As Judge et al. openness to experience was positively correlated with extrinsic success (1999). High scores of openness to experience indicate an extensive intellectual curiosity with individualistic and non-conforming ways of thinking and behaving (Migliore 2011) which can be taken as determinants of own career path. Therefore the following hypothesis was derived;

$\mathrm{H}_{2}$ : There is a positive relationship between openness to experience and subjective career success of the employees in Sri Lankan banking sector.

The cooperative nature of agreeable individuals may lead to more successful careers, predominantly in jobs where teamwork or customer service is relevant (Judge et al. (1999). The characteristics of agreeable persons which are trusting others, caring as well as goodnatured, cheerful, and gentle qualities are related to career success (Judge et al. 1999). In light of the literature and research findings following hypothesis was formulated;

$H_{3}$ : There is a positive relationship between agreeableness and objective career success of the employees in Sri Lankan banking sector.

Judge et al. (1999) stated that conscientiousness positively influenced subjective and objective career success. Conscientiousness may influence extrinsic career success through its influence on job performance (Barrick \& Mount 1991) and also it most constantly related to performance across jobs (Barrick \& Mount 1991; Salgado 1997). Following hypotheses were derived based on the above literature.

$H_{4}$ : There is a positive relationship between conscientiousness and objective career success of the employees in Sri Lankan banking sector.

$H_{5}$ : There is a positive relationship between conscientiousness and subjective career success of the employees in Sri Lankan banking sector.

Neuroticism negatively impact on objective career success (Bozionelos 2004; Judge et al. 1999). Because of their tendency to interpret experiences under negative light, individuals who score high on neuroticism should be less likely to develop positive attitudes towards their work (Bozionelos 2004). According to the findings of Bozionelos (2004) neuroticism impedes ultimate extrinsic career accomplishment, and they further suggest that 
agreeableness primarily and neuroticism secondarily also obstruct organization-specific career attainment. In light of this literature the following hypotheses were developed;

$H_{6}$ : There is a negative relationship between neuroticism and objective career success of the employees in Sri Lankan banking sector

$H_{7}$ : There is a negative relationship between neuroticism and subjective career success of the employees in Sri Lankan banking sector.

Based on the above hypotheses following three hypotheses were developed in order to identify the impact of personality on career success.

$H_{8}$ : Extroversion, agreeableness, conscientiousness and neuroticism have an impact on objective career success

$H_{9}$ : Openness to experience, neuroticism and conscientiousness have an impact on subjective career success.

$H_{10}:$ There is an impact of Personality on career success.

Figure 01: Conceptual Model

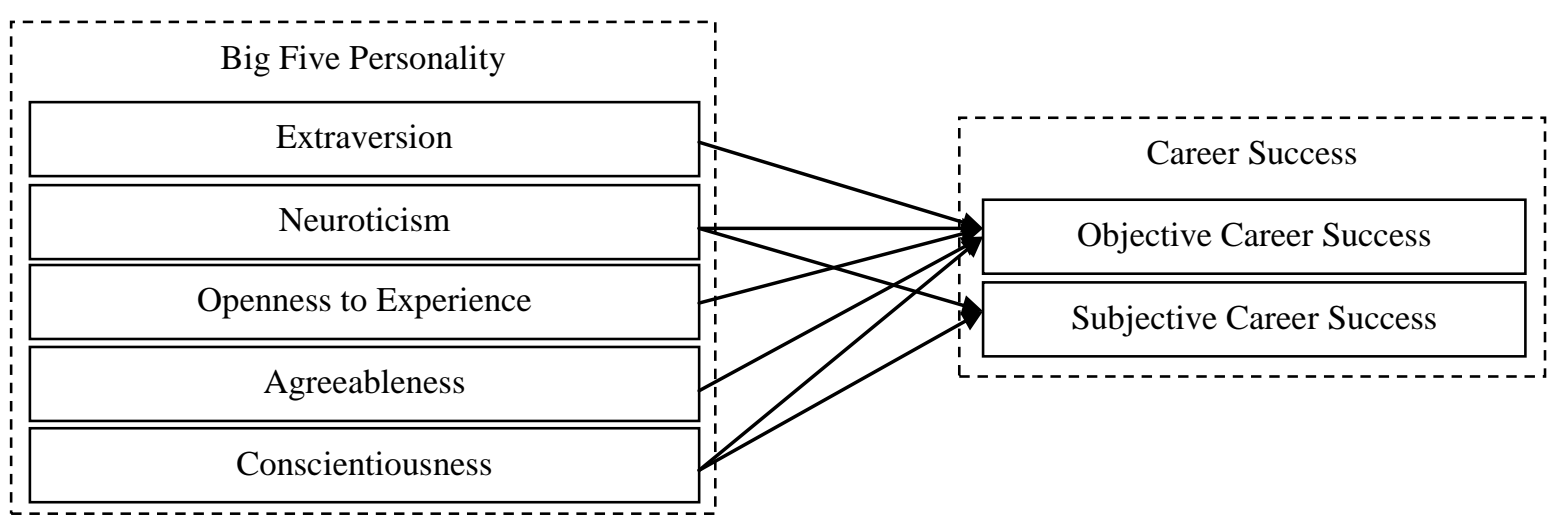

The above expanded model explains dimensions of both personality and career success and the hypotheses were developed based on former findings. Among various models of personality, the Big Five model was selected for the research purpose. The impact of five dimensions on both objective and subjective career success is depicted in the above theoretical framework.

\section{Method}

The objective of this study was to delineate the impact of personality on career success of the Sri Lankan banking sector employees. This study is causal in nature. This study was conducted in a quantitative design by collecting data through a questionnaire and the characteristics of the personality and career success are described in this study. These types of studies usually explain the nature of certain relationships and explain the variance in the dependent variable.

Sri Lankan banking sector employees were the population of this study. The sample consisted of 150 employees from state and private commercial banks in western province in Sri Lanka. For selecting the employees or individuals for the study stratified random sampling was used. 
The employees in one bank were divided into different subgroups based on the grades (position of the job) and then the individuals were selected on random base. This research was conducted in a non-contrived setting which is not artificial and since the data was gathered at once they can be considered as a cross sectional study.

\section{Measures}

A questionnaire was used to collect data on personality types and career success of the individuals since it was more convenient to contact the employees with hectic work schedules. The questionnaire was designed in a way it could measure the variables in the conceptual model. Some of the questions used in the questionnaire were well accepted questions and some of them have been developed by the researchers for the particular research area.

Questions for measuring personality were taken from the BFI inventory developed by Oliver P John in 1991 and act as a prototype for the original NEO personality model (John, Hampson \& Goldberg 1991). This is a shorter version of NEO personality inventory developed by Costa and McCrae in 1992. This inventory consists of 44 items which separately describe five dimensions of the big five personality model and used to measure personality orientation of the employees in Sri Lankan banking sector.

The questions set to measure subjective career success were abstracted from the career satisfaction scale developed by Greenhaus, Parasuraman and Wormley in 1990. Besides, objective career success was measured using four questions which have been used for many other research studies. For an example Abele, Spurk and Volmer (2011) mentioned this in their research article on "The construct of career success: measurement issues and an empirical example".

\section{Validity and Reliability}

Since standard questions were used for this research study to measure both personality and career success the construct validity of the questionnaire was ensured. The internal item consistency reliability was examined with Cronbach's Alpha test (Kottawatta 2014). To measure reliability Cronbach's alpha, the reliability coefficient was obtained for both variables using SPSS 16.0 Version. This reliability coefficient indicates how well the items in a set are positively correlated to one another and this is computed in terms of the average inter-correlations among the items measuring the concept. The Cronbach's alpha for 44 item personality inventory is .686 and .647 for career success which consist of 11 question items. The content validity of the instruments was ensured by the conceptualization and operationalization of the variables using available literature and indirectly by the high internal consistency reliability of the instruments as denoted by the Alphas (Kottawatta 2014).

Table 01: Reliability (Pilot Test)

\begin{tabular}{|l|c|c|}
\hline Variable & Cronbach's Alpha & No of Items \\
\hline Personality & .664 & 44 \\
\hline Career Success & .863 & 11 \\
\hline
\end{tabular}




\section{Techniques of Data Analysis}

After gathering data they were analyzed using SPSS 16.0 (Version). Correlation analysis and regression analysis were used to analyze data for the research study.

\section{Results}

First the demographic variables of gender, age and marital status were analyzed in relation to the selected sample. In this study, $61.5 \%$ of front line employees were females, while $38.5 \%$ were males $.16 .3 \%$ respondents were below 25 years, $14.1 \%$ were between the age of 25 years to 35 years, $14.1 \%$ were between the age of 36 years to 45 years, $7.4 \%$ were between the age of 46 years to 55 years and $14.8 \%$ respondents were above the age of 55 years. Out of 135 respondents, the job tenure of $14.1 \%$ were less than 1 year, $20.0 \%$ were in between 1 to two years, $19.3 \%$ were in between 3 to 5 years, $16.3 \%$ were in between 6 to 10 years and $30.4 \%$ were over 10 years.

Table 02 presents the Pearson correlation for the relationship between independent variables and dependent variable of the research model.

Table 02: Correlation between Independent Variables and Dependent Variables

\begin{tabular}{|c|c|c|c|c|c|c|}
\hline & & 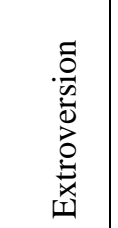 & 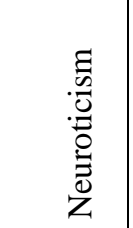 & 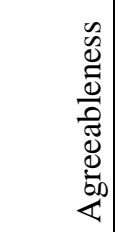 & 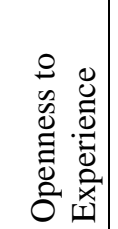 & 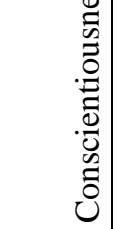 \\
\hline \multirow[t]{2}{*}{ Objective Career Success } & Pearson Correlation & $.104 *$ & $-.259 * *$ & $.226 * *$ & $.097 *$ & $.119 *$ \\
\hline & Sig. (1-tailed) & .114 & .001 & .004 & .133 & .085 \\
\hline \multirow[t]{2}{*}{ Subjective Career Success } & Pearson Correlation & $.223 * *$ & $-.426 * *$ & $.200 *$ & $.345 * *$ & $.311^{* *}$ \\
\hline & Sig. (1-tailed) & .005 & .000 & .010 & .000 & .000 \\
\hline
\end{tabular}

According to the Pearson Correlation (Table 02), there is a weak positive relationship between extroversion and objective career success $[\mathrm{r}=.104, \mathrm{p}=0.114$, one tailed]. The significance level or the $\mathrm{p}$ value is 0.114 and it indicates that this relationship does not statistically significant. Therefore, according to the results the null hypothesis is rejected and the alternative hypothesis is accepted. Hence the data support the hypothesis that there is a positive relationship between extraversion and objective career success of the employees in Sri Lankan banking sector. According to the statistics in Table 2 there is a very weak positive relationship between openness to experience and objective career success $[r=0.097, p=0.133$, one tailed]. Significant level 0.133 indicates that the relationship is not statistically significant. Agreeableness and objective career success positively correlate indicating weak relationship [ $\mathrm{r}=0.226, \mathrm{p}=0.004$, one tailed]. The relationship is statistically significant as correlation is significant at 0.004 level (1-tailed). Thus there is statistical evidence to claim that agreeableness and objective career success are positively correlated. Conscientiousness 
and objective career success positively correlates indicating weak relationship $[\mathrm{r}=0.119$, $\mathrm{p}=0.085$, one tailed]. Pearson correlation for the conscientiousness and subjective career success is 0.311 which indicates low positive relationship under the significance level of 0.000. This indicates that there is statistical evidence to claim that conscientiousness and subjective career success are positively correlated. There is a weak negative relationship between neuroticism and objective career success with 0.001 significance level $[r=-0.259$, $\mathrm{p}=0.001$, one tailed]. Since the $\mathrm{p}$ value is below 0.01 it can be concluded that the relationships are statistically significant. This indicates that there is statistical evidence to claim that neuroticism and objective career success are negatively correlated. The relationship between neuroticism and subjective career success is moderately negative correlates $[\mathrm{r}=-0.426$, $\mathrm{p}=.000$, one tailed].

Relationship between Neuroticism, Extroversion, Conscientiousness, Agreeableness and Objective Career Success

The model summary of the simple regression for the above relationship is given in Table 03 .

Table 03: Model Summary of Neuroticism, Extroversion, Conscientiousness, Agreeableness and Objective Career Success

\begin{tabular}{|c|c|c|c|c|c|c|}
\hline \multicolumn{2}{|c|}{$\mathrm{R}$} & $.302^{\mathrm{a}}$ & & & & \\
\hline \multicolumn{2}{|c|}{ R Square } & .091 & & & & \\
\hline \multicolumn{2}{|c|}{ Adjusted A square } & .063 & & & & \\
\hline \multicolumn{2}{|c|}{ Std. Error of the Estimate } & .86072 & & & & \\
\hline \multirow{2}{*}{\multicolumn{2}{|c|}{ Model 1}} & \multicolumn{2}{|c|}{ Unstandardized Coefficients } & \multirow{2}{*}{\begin{tabular}{|r}
$\begin{array}{l}\text { Standardized } \\
\text { Coefficients }\end{array}$ \\
Beta
\end{tabular}} & \multirow[b]{2}{*}{$\mathrm{t}$} & \multirow[b]{2}{*}{ Sig. } \\
\hline & & $\mathrm{B}$ & Std. Error & & & \\
\hline \multirow[t]{5}{*}{1} & (Constant) & 3.261 & .910 & & 3.583 & .000 \\
\hline & Extroversion & -.085 & .141 & -.069 & -.602 & .548 \\
\hline & agreeableness & .269 & .159 & .215 & 1.686 & .094 \\
\hline & Conscientiousness & -.117 & .131 & -.094 & -.893 & .373 \\
\hline & neuroticism & -.379 & .167 & -.236 & -2.265 & .025 \\
\hline
\end{tabular}

a. Dependent Variable: objective career success

According to Table 03, the multiple $\mathrm{R}$ is 0.302 . $\mathrm{R}$ Square of 0.091 indicates that $9.1 \%$ of the variance in objective career success is explained by neuroticism, extroversion, conscientiousness and agreeableness. The $\mathrm{p}$ value of each variable indicates the predictive ability of the variables as a model. $\mathrm{P}$ value of neuroticism which is 0.025 indicates that there is a high predictive ability in the variable of neuroticism on the model. The data support that neuroticism, extroversion, conscientiousness and agreeableness have an impact on objective career success.

Relationship between Openness to Experience, Neuroticism, Conscientiousness and Subjective Career Success

The model summary of the simple regression for the above relationship is given in Table 04 . 
Table 04: Model Summary of Openness to Experience, Neuroticism, Conscientiousness and Subjective Career Success

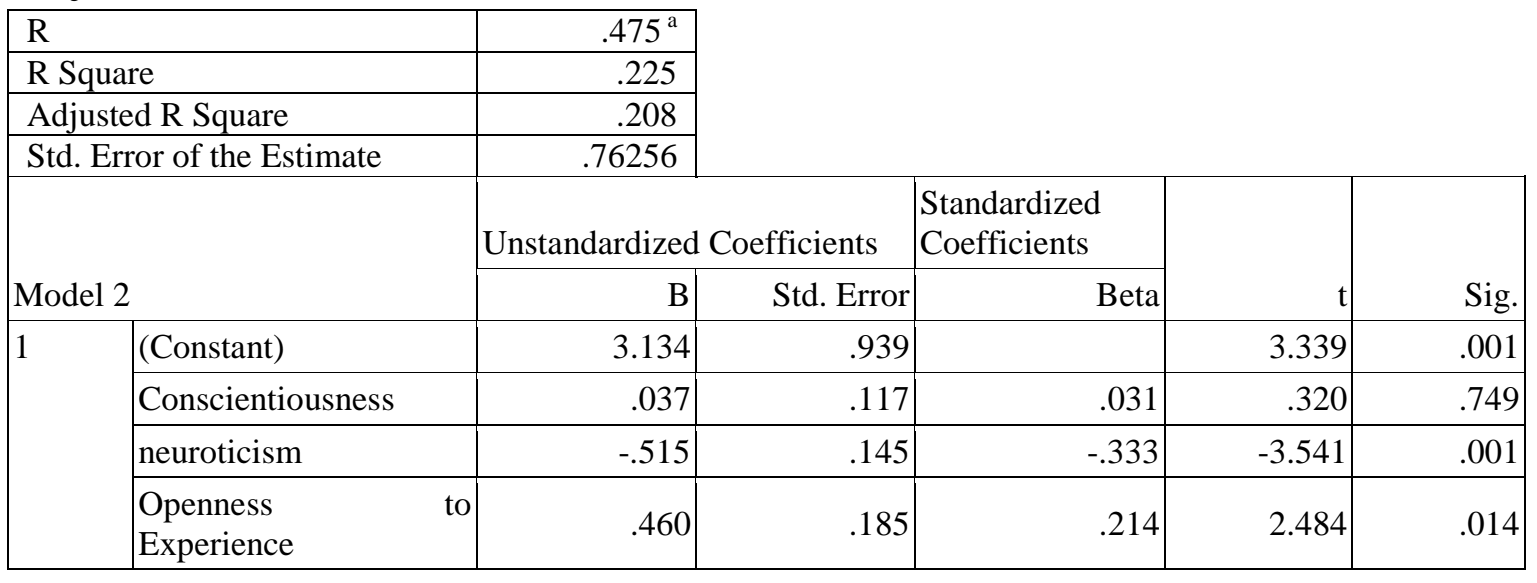

a. Dependent Variable: subjective career success

The multiple $\mathrm{R}$, as Table 4, is 0.475 . $\mathrm{R}$ Square of 0.225 indicates that $22.5 \%$ of the variance in subjective career success is explained by openness to experience, neuroticism and conscientiousness. $\mathrm{P}$ value of each variable indicates the predictive ability of the variables as a model. $\mathrm{P}$ value of the openness to experience and neuroticism which are 0.001 and 0.014 indicates that there is a high predictive ability in the variable of openness to experience and neuroticism on the model.

\section{Impact of the Personality on Career Success}

The model summary of the simple regression for the above relationship is given in Table 05 .

Table 05: Model Summary of Personality and Career Success

\begin{tabular}{|c|c|c|c|c|c|c|}
\hline \multicolumn{2}{|c|}{$\mathrm{R}$} & $.227^{\mathrm{a}}$ & & & & \\
\hline \multicolumn{2}{|c|}{ R Square } & .051 & & & & \\
\hline \multicolumn{2}{|c|}{ Adjusted R Square } & .044 & & & & \\
\hline \multicolumn{2}{|c|}{ Std. Error of the Estimate } & .70970 & & & & \\
\hline \multirow{2}{*}{\multicolumn{2}{|c|}{ Model 3}} & \multicolumn{2}{|c|}{ Unstandardized Coefficients } & $\begin{array}{l}\text { Standardized } \\
\text { Coefficients }\end{array}$ & \multirow[b]{2}{*}{$\mathrm{t}$} & \multirow[b]{2}{*}{ Sig. } \\
\hline & & $\mathrm{B}$ & Std. Error & Beta & & \\
\hline \multirow[t]{2}{*}{1} & (Constant) & 1.440 & .647 & & 2.227 & .028 \\
\hline & personality & .486 & .181 & .227 & 2.685 & .008 \\
\hline
\end{tabular}

a. Dependent Variable: career success

According to Table 05, multiple $\mathrm{R}$ is 0.227 and $\mathrm{R}$ Square of 0.051 indicates that $5.1 \%$ of the variation in career success is explained by five dimensions.

\section{Discussion and Conclusion}

It was found that there is a positive relationship between extroversion and objective career success of the employees in Sri Lankan banking sector with a correlation of 0.104. This finding was in line with the previous research (Thomas et al. 2005). As literature suggested people with extraversion has the tendency to be sociable, outgoing, talkative and warmhearted. Since banking is a service providing industry which requires high level of 
interaction and enthusiasm it can be said that extraversion and objective career success of the employees are positively related. The data analysis showed that there is a positive relationship between openness to experience and subjective career success. This finding is supported by the previous research done by Thomas et al. (2005). It was found that there is a positive relationship between agreeableness and objective career success. In agreement with the findings of the Barrick and Mount (1991), the hypothesis that there is a positive relationship between conscientiousness and objective career success was supported by the data of this study. This was however a weak positive (correlation coefficient .119) relationship. It was found that correlation between conscientiousness and subjective career success is also positive but with a higher value. This could be because that the respondents of the study may be intrinsically motivated due to the nature of the work they are engaged in as well as the economic rewards they receive and the perception in the society about banking jobs.

It was hypothesized that there is a negative relationship between neuroticism and objective and subjective career success. Based on Judge et al. (1999) and Thomas et al. (2005) it can be said that this study also proved that there is a negative relationship between neuroticism and objective and subjective career success. As literature suggest people with neuroticism has a tendency to worry unnecessarily low self confidence and most of the times emphasize negative emotions. So that it can be said that neuroticism is negatively related with career success.

When considering the impact of personality and career success, it was found that extroversion, agreeableness, openness to experience, conscientiousness and neuroticism have an impact on objective career success whereas openness to experience, neuroticism and conscientiousness have an impact on subjective career success. In agreement with Barrick, Mount and Gupta (2003) it was proven that there is an impact of individual's personality on his or her career success.

\section{References}

i. Abele, AE, Spurk, D \& Volmer, J 2011, 'The construct of career success: Measurement issues and an empirical example', Journal for Labour Market Research, Vol. 43, pp. 195-206.

ii. Barrick, MR \& Mount, MK 1991, 'The big five personality dimensions and job performance: A meta-analysis', Personnel Psychology, Vol. 44, pp. 1-26.

iii. Barrick, MR, Mount, MK \& Gupta, R 2003, 'Meta-analysis of the relationship between the five-factor model and Holland's occupational types', Personnel Psychology, Vol. 56, pp. 45-74.

iv. Bozionelos, N 2004, "The big five of personality and work involvement", Journal of Managerial Psychology, Vol. 19, No. 1, pp. 69-81.

v. Greenhaus, JH, Parasuraman, S \& Wormley, WM 1990, 'Effects of race on organizational experiences, job performance evaluations, and career outcomes', Academy of Management Journal, Vol. 33, pp. 64-86. doi:10.2307/256352. 
vi. Judge TA, Cable, DM, Boudreau, JW \& Bretz, RD 1995, 'An empirical investigation of the predictors of executive career success', Personnel Psychology, Vol. 48, No. 3, pp. 485-519.

vii. Judge, TA, Higgins, CA, Thoresen, CJ \& Barric, MR 1999, 'The Big Five personality traits, General mental ability, and career success across the life span', Personnel Psychology, pp.621-652.

viii. Kottawatta, H 2014, Research guide book, Department of Human Resource Management, Colombo.

ix. Lau, VP and Shaffer, MA 1999, 'Career Success: the effects of personality', Career Development International, pp.225-230.

x. McCrae, RR, \& Costa, PT Jr. 1995, 'Domains and Facets: Hierarchical Personality Assessment Using the Revised NEO Personality Inventory', Journal Of Personality Assessment, Vol. 64, No. 1, pp. 21-50.

xi. Melamed, T 1996, 'Career success: An assessment of a gender- specific model', Journal of Occupational and Organizational Psychology, Vo. 69, pp. 217- 242.

xii. Migliore, LA 2011, 'Relation between big five personality traits and Hofstede's cultural dimensions Samples from the USA and India', Cross Cultural Management: An International Journal, Vol. 18, No. 1, pp. 38-54.

xiii. Salgado, JF 1997, 'The five factor model of personality and job performance in the European Community', Journal of Applied Psychology, Vol. 82, pp. 30-43.

xiv. Simonetti, JL 1999, 'The key pieces of the career survival and success puzzle', Career Development International, No. 4/6, pp. 312-317.

xv. Toit, DM \& Coetzee, M 2012, 'Exploring the perceived career success of staff in a South African science and engineering company', Journal of Psychology in Africa, Vol. 22, No. 1, pp. 96-105.

xvi. John, OP, Hampson, SE \& Goldberg, LR 1991, 'Is there a basic level of personality description?', Journal of Personality and Social Psychology, No. 60, pp. 348-361.

Dodangoda, HC

Department of Human Resource Management, University of Sri Jayewardenepura

Arachchige, BJH

Senior Lecturer, Department of Human Resource Management, University of Sri Jaye wardenepura 